\title{
Assessing the nanotechnology on the grounds of costs, benefits, and risks
}

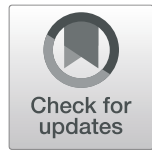

\author{
Garima Pandey ${ }^{*}$ (D) and Pallavi Jain
}

\begin{abstract}
Background: The technical innovations are based on the principles of science with the assurance of outweighing their cost and risk factors with the benefits to society. But sometimes, the innovation either itself becomes a risk or brings in some risk factors along with it. For most of the alleyway of an innovation from its emergence to its road to societal acceptance and adoption, the focus remains on the benefits majorly. Only when we are at the neck of the hour we think about some of the apparent cost and risk issues. The understanding, proper communication, and address of the basics of risk factors are necessarily required much in advance to deal with this issue.

Main body: Nanoparticles with very small size and huge surface area are being derived from various plants, microbes, chemical compounds, metals, and metal alloys. Without our realizations, nanotechnology has become a vital part of our day-to-day life, and nanoparticles are proving their worth in almost every field ranging from food, water, medicine, agriculture, construction, fashion, electronics, and computers to eco-remediation, but what about the costs involved and the risks associated? We strongly need to recognize these concerns and challenges, and it requires collaborative efforts from academicians, researchers, industries, government, and non-government organizations to involve people in dialogs to deal with them.

Conclusion: Through reviewing various studies and articles on nanotechnology, this review has shown that nanotechnology can productively be used to produce consumer goods for pharma, electronics, food, agriculture, aviation, construction, security, and remediation sectors which are advantages in their characteristics. Regarding the future of nanotechnology, we need to focus on assessment and management of risks associated for its promising market growth.
\end{abstract}

\section{Background}

The growth of nanotechnology has paved the way for new innovations in various areas, including agriculture, food, medicine, textile, and electronics. Some of these are already been established and marketed while several others are still under their laboratory stage [1-3]. Various applications of nanotechnology and designed nanostructures may bring desirable advances to mankind and environment, but they may have health and ecological implications resulting into extensive risks to society. Owing to their adjustable physicochemical properties like thermal-electrical properties, melting point, catalytic

\footnotetext{
*Correspondence: Garimapandey.pandey8@gmail.com; garimap@srmist.edu.in

SRM Institute of Science and Technology, Delhi NCR Campus, Modinagar, India
}

(c) The Author(s). 2020 Open Access This article is licensed under a Creative Commons Attribution 4.0 International License, which permits use, sharing, adaptation, distribution and reproduction in any medium or format, as long as you give appropriate credit to the original author(s) and the source, provide a link to the Creative Commons licence, and indicate if changes were made. The images or other third party material in this article are included in the article's Creative Commons licence, unless indicated otherwise in a credit line to the material. If material is not included in the article's Creative Commons licence and your intended use is not permitted by statutory regulation or exceeds the permitted use, you will need to obtain permission directly from the copyright holder. To view a copy of this licence, visit http://creativecommons.org/licenses/by/4.0/.

behavior, and photo activity, nanomaterials have garnered prominent attention from the researchers worldwide [4, 5]. As per the definition given by ISO, nanomaterials are defined as "Material with any external nanoscale dimension or having internal nanoscale structure" [6, 7]. Based on the above definition, various structures of nanoscale dimensions are named as nanowires, quantum dots, nanoplates, etc. Based on the nature of base material used for the production, nanomaterials can be broadly categorized into 4 categories (Table 1 ).

All these types of nanoparticles possess various advantageous characteristics which makes them highly useful for a range of applications Table 2 [8-11].

Along with these positive attributes, nanotechnology might bring-in some significant negative implications on 
Table 1 Categories of nanomaterials

\begin{tabular}{|c|c|c|}
\hline SN & Base material & Example \\
\hline i. & Bio-organic & Dendrimers, micelles, liposomes \\
\hline ii. & Carbon & $\begin{array}{l}\text { Carbon nanotubes, fullerenes, carbon } \\
\text { nanofibers, carbon black }\end{array}$ \\
\hline iii. & $\begin{array}{l}\text { Metal and metal } \\
\text { oxide based }\end{array}$ & $\mathrm{Ag}, \mathrm{Au}, \mathrm{Ti}, \mathrm{Fe}, \mathrm{Pt}, \mathrm{Pd}, \mathrm{Sn}, \mathrm{Cu}$ nanomaterials \\
\hline iv. & Composite based & $\begin{array}{l}\text { Polymer, composite combinations of carbon- } \\
\text { based, metal-based, or organic-based NMs } \\
\text { with any form of metal, ceramic, or polymer } \\
\text { bulk materials. }\end{array}$ \\
\hline
\end{tabular}

society, economy, and environment Table 3 [11-13]. These effects can be summed up in the following ways.

Therefore, it is call of the hour to focus on finding new provisions of increasing the transparency and traceability of nanomaterials through precise assessments and management of all the risk factors associated [14-16]. This article aims to present a summary of existing applications, risks, and legislations as well as some further developments related to nanotechnology and nanostructures.

\section{Main text}

\subsection{Applications, benefits, and services of nanotechnology}

Nanotechnology is all about designing, characterization, application, production, and marketing of structures on nanoscale dimensions. The interdisciplinary field of nanotechnology is accepted as a window of new opportunities for providing solutions not only in the core technical areas but also promisingly addressing developmental issues like water treatment, eco-remediation, and sustainable energy [17-20]. The broad relevance of nanotechnology accentuates the manipulation, categorization, and creation of nanoscale materials [21, 22]. Nanotechnology has proven its relevance in almost every area of life, be it agriculture, medical, electronics, fashion, environment, or construction [23-25].
Nanomaterials are the natural or engineered substances with dimensions between 1 and $100 \mathrm{~nm}$. Playing with matter on nanoscale is a revolutionary technology as nanosize exposes a unique world of physiochemical, biological, and toxicological properties. At nanoscale, it is the surface behavior along with quantum behavior that brings about remarkable changes in the properties of matter [16, 26, 27]. The quantum effect gives nanomaterials very diverse physical, chemical, thermal, electrical, optical, and magnetic properties. Materials gain strength and resistance at the nanoscale, their color and light reflecting characteristics get altered, and reduction of size increases the surface area which results in alteration of physiochemical properties of the particle which leads to increased mobility, reactivity, and better aggregation and dissolution properties [28]. The various applications of nanotechnology are summarized in Table 4.

Nanosilver is used as an antimicrobial agent in cleaning sprays and for disinfecting the chopping boards, food containers, and refrigerator boxes. Nanoclay and nanocomposites are employed to decrease the costs and to increase the strength and shelf life of carbonated and noncarbonated drinks [71, 72]. Nanosensor-based packaging films are utilized for safe and hygienic packing and delivery of food items and improving their shelf life [73, 74]. Cost-effective nanopurification systems for water treatment can resolve the global problem of drinkable water. It is expected that by the year 2030, the world will observe an increase of $60 \%$ in the water demand globally $[26,27]$. Silver- and chitosan-based nanofilters can play a substantial part in producing drinking water from sea water, thus providing solution to the increasing global demand of fresh water. Nano-based technologies will create enormous ecological paybacks in the area of water treatment through improving the analysis, monitoring, disinfection, desalination, water conservation, recycling, and sewerage systems [75-78]. After water and food resources, energy is proved to be the fundamental resource for mankind, and the ever rising demand for energy

Table 2 Characteristic properties of nanomaterials

\begin{tabular}{|c|c|c|}
\hline SN & Properties & Examples \\
\hline 1. & Catalytic property & $\begin{array}{l}\text { Enhanced surface-volume ratio } \\
\text { Better catalytic efficiency }\end{array}$ \\
\hline 2. & Electrical property & $\begin{array}{l}\text { Improved electrical resistance } \\
\text { Enhanced electric conductance }\end{array}$ \\
\hline 3. & Mechanical property & $\begin{array}{l}\text { Improved magnetism } \\
\text { Super-paramagnetic performance }\end{array}$ \\
\hline 4. & Optical property & $\begin{array}{l}\text { Better toughness and hardness } \\
\text { Enhanced plasticity and ductility of ceramics }\end{array}$ \\
\hline 5. & Sterical property & $\begin{array}{l}\text { Positive shift in optical absorption and fluorescence } \\
\text { Improved quantum efficiency of semiconductors }\end{array}$ \\
\hline 6. & Biological property & $\begin{array}{l}\text { Improved selectivity of chemicals } \\
\text { Controlled release and improved drug transformations }\end{array}$ \\
\hline
\end{tabular}


Table 3 Negative effects of nanotechnology on society

\begin{tabular}{ll}
\hline 1. Ethical & Social divides, technology abuse \\
influence & \\
2. Social & Environmental hazards, health risks, economic effects, \\
influence & educational avenues \\
3. Legal & Privacy breach, regulations, property rights \\
influence & \\
\hline
\end{tabular}

resources is expected to climb by $50 \%$ by the year 2025 . Currently the major sources are the natural energy resources from fossil fuels which are expected to bear double the current burden by 2025 [79, 80]. Nanotechnology has the potential to provide solutions to the global energy demands through cost-effective nanofuel cells, hydrogen storage nanosystems, nanocoated solar cells, and reinventing the energy storage and energy distribution. Nanodevices can track alterations in the glucose level, cholesterol level, and carbon dioxide level of the body without extracting blood; nanobots can help repair or replace the damaged body tissues in injured body; nanosolutions can restore youth and health of aging skin. In the medical field, nanotechnology aids drug delivery methods, tissue engineering, treatment systems, regenerative medicines, cell repair, cancer detecting and treating cancerous patients, gene-therapy, etc. $[81-83]$.

\subsection{Market needs of nanomaterials}

The growing acceptance of nanotechnology by the society is creating the demand for nano-inspired goods. This is also highlighting the necessity of understanding the potential effects these products would be having on environment, eco-balance, animals, and human beings. In the year 2019, the global market of nanomaterials was estimated to be 8.5 billion US dollars and is anticipated to grow with an annual rate of $13.1 \%$ from the year 2020 to the year 2027 [84-87]. This rise in market share of nanotechnology is attributed to the rapid acceptance and adoption of nanostructures in aerospace applications, medical and health sectors, food and packaging industry, agriculture and farming, sports, cosmetics, constructions, paints and coatings, electronics, environmental remediation power and energy sectors, etc. The key factor for this growing market of nanomaterials is the characteristic physical, chemical, and biological properties of metal nanoparticles. Copper, silver, platinum, gold, aluminum, palladium, zinc, tellurium, titanium metals, and their oxide-based nanoparticles along

Table 4 Applications of nanotechnology

$\mathrm{S}$ Application Example

N.

1. Energy storage, production, and Nanomaterials as catalysts for hydrogen production, carbon nanotubes for hydrogen storage and as conversion composite coatings in solar cells, quantum dot-based light-emitting devices and photo-voltaic cells, grapheme-based ultra-capacitors, hybrid protein-polymer bio-mimetic membranes produced from protein hybrid polymer [29-34]

2. Agricultural productivity enhancement

Nanocapsules for precision farming; nanoporous zeolites for the precise and sustained release of nutrients, pesticides, herbicides, drugs for livestock and plants, and efficient dosage management of water; nanosensors for monitoring of plants and soil health and pest control; nanomagnets for removing soil contaminants [3538].

3. Air and water remediation

Nanomembranes, metal oxide nanoparticles, magnetic nanoparticles, nanosensors, nanoporous zeolites, and grapheme-based treatment structures or detection of pollutants and remediation of air and water [39-43].

4. Disease diagnosis and drug

Carbon nanotube sensors, quantum dots, conjugates of dendrimer and antibody, as the detection and delivery diagnosis medical tools to act as sensors and in situ examinations of diseases and sustained drug release [4448]

5. Food storage and processing

Silver and zinc oxide nanomaterials for antimicrobial actions; nanoemulsions and nanocomposites for foodpackaging, storing, and decontamination; silver, silica, selenium, iron, platinum, titanium dioxide, calcium, and magnesium as nanosupplements [49-51].

6. Constructions

Nanomaterials for cost management, weathering management, and durability of coatings, paints, surfaces, concrete materials, adhesives, and photosensitivity of constructions [52-55]

7. Social-security

Detection systems based on nanotechnology $[56,57]$

8. Academics

Improved communication systems through better band-width and lower cost [58]

9. Beauty and cosmetic

Nano-based age-defying creams, ethosome- and liposome-based hair-care products, sunscreen lotions [5963].

10. Sports

Nanotechnology-based golf/tennis balls, bow-arrows, helmets for football, bats for baseball, racquets for badminton and tennis, racing bicycles, sticks for hockey, etc. [64, 65].

11. Electronics 
with carbon-based nanostructures are broadly being used in various consumer products.

\begin{tabular}{lllll}
\hline $\begin{array}{l}\text { Revenues } \\
\text { in \$ } \\
\text { billions }\end{array}$ & $\begin{array}{l}\text { Annual } \\
\text { growth rate } \\
\mathbf{2 0 0 0 - 2 0 1 0}\end{array}$ & $\begin{array}{l}\text { Annual } \\
\text { growth rate } \\
\mathbf{2 0 1 0 - 2 0 1 3}\end{array}$ & $\begin{array}{l}\text { Estimated } \\
\text { growth for } \\
\text { year 2020 }\end{array}$ & $\begin{array}{l}\text { Estimated } \\
\text { growth for } \\
\text { year 2030 }\end{array}$ \\
\hline World & $25 \%$ & $48 \%$ & 3000 & 30,000 \\
USA & $24 \%$ & $38 \%$ & 750 & 7500 \\
\hline
\end{tabular}

Source: data from Roco et al. and from Lux Research $[88,89]$

The area of nanotechnology is continuously attracting investments from all over the world with the USA and China leading the list. This inflow of funds is rendering the process of integration of manufactured nanomaterials into the finished market product. With this interest and funding, it is expected that the market for nanotechnology will expectedly grow with 17\% CAG rate in the span of 7 years from the year 2018 to 2025 . The optimistic market trend reflects the balanced collaborations between research, industry, and society.

\subsection{Sources and synthesis of nanomaterials}

As nanomaterials have proven their worth in almost every aspect of societal problems, we need to get them extracted naturally or produced synthetically (Table 5) [96, 97].

Nanoparticles can be synthesized through various physiochemical or biological methods (Fig. 1). The physical methods of synthesizing nanoparticles are enormously expensive whereas chemical routes pose serious environmental risks along with the issues of slow growth rate and inaccuracy in the structure of the designed nanoparticle. Nanomaterials are being synthesized as per the following two approaches [98-101]:

- Bottom-up approach-this approach begins with initial structures at atomic level. It is a cost-effective method for large scale productions.

- Top-down approach-this approach begins with the initial structures at macroscopic level. It is a slow method and not cost-effective for large scale productions. Hydrothermal synthesis

Table 5 Sources of nanomaterials

\begin{tabular}{lll}
\hline S.N & Source & Example \\
\hline 1. & $\begin{array}{l}\text { Incidental } \\
\text { nanomaterials }\end{array}$ & $\begin{array}{l}\text { Nanoparticles from forest fire, dust storm, } \\
\text { cosmic evolutions, volcanic eruptions, etc. } \\
{[90] .}\end{array}$ \\
2. $\begin{array}{l}\text { Engineered } \\
\text { nanomaterials }\end{array}$ & $\begin{array}{l}\text { Nanoparticles synthesized in the laboratory, } \\
\text { released from the exhausts of engines, } \\
\text { construction, and demolition works, found } \\
\text { in health care and biomedical products [91- } \\
\text { 93]. }\end{array}$ \\
3. $\begin{array}{l}\text { Naturally produced } \\
\text { nanomaterials }\end{array}$ & $\begin{array}{l}\text { Nano-organisms, viruses, nanobacteria, } \\
\text { magneto-tactic bacteria, etc. [94, 95]. }\end{array}$ \\
\hline
\end{tabular}

Synthesizing nanoparticles from chemical solutions can be achieved by the following routes [54, 102, 103]:

- Colloid-based synthesis

- Microemulsion-based synthesis

- Hydrothermal-based synthesis

- Solvothermal synthesis

- Chemical vapor-deposition synthesis

- Thermal-decomposition synthesis

- Pulsed laser-ablation synthesis

- Template-based synthesis

- Combustion

- Gas phase methods

- Microwave synthesis

- Conventional sol-gel method

In order to minimize the environmental risks from physiochemical synthesis, researchers are looking out for sustainable and green synthesis of nanoparticles. The green methods are comparatively faster in terms of reaction rate and are cost effective and less hazardous to the environment. Green synthesis of nanoparticles involves mixing of appropriate amount of metal ions with plant extracts or microorganisms under requisite conditions (Fig. 2) [26, 27].

\subsection{Risks of nanotechnology}

Anticipated benefits of nanotechnology integrate enhanced efficiency, improved bio-accessibility, and sophisticated packaging. These novel products or constituents may pretense a threat to humans and environment. There are global efforts for addressing and regulating the manufacturing and secure management/applications of nanotechnologies either by advices and supervision or by legislations [104, 105]. Presently, there is no law wholly committed to the directives focusing towards nanotechnologies in any of the countries globally [106, 107]. Existing laws are being considered as adequate and precise enough for regulating the uses of nanotechnology [108, 109] though some modifications have been recommended by numerous policy-making bodies like various NGOs and the European parliament [110, 111]. The call for supplementary directions to evaluate the impending hazards and for suggestions to guarantee the secure utilization of nanotechnology is being recognized, and quite a few specialist organizations are working actively in this area, for instance the Organization for Economic Cooperation and Development (OECD), the International Standard Organization (ISO), or the US Food and Drug Administration (FDA) [112, 113]. The recent review article presents a sketch of the assessment of disputes and threat issues related to nanomaterials and indicates that these characteristics are straightly linked to the methods used for their synthesis. 


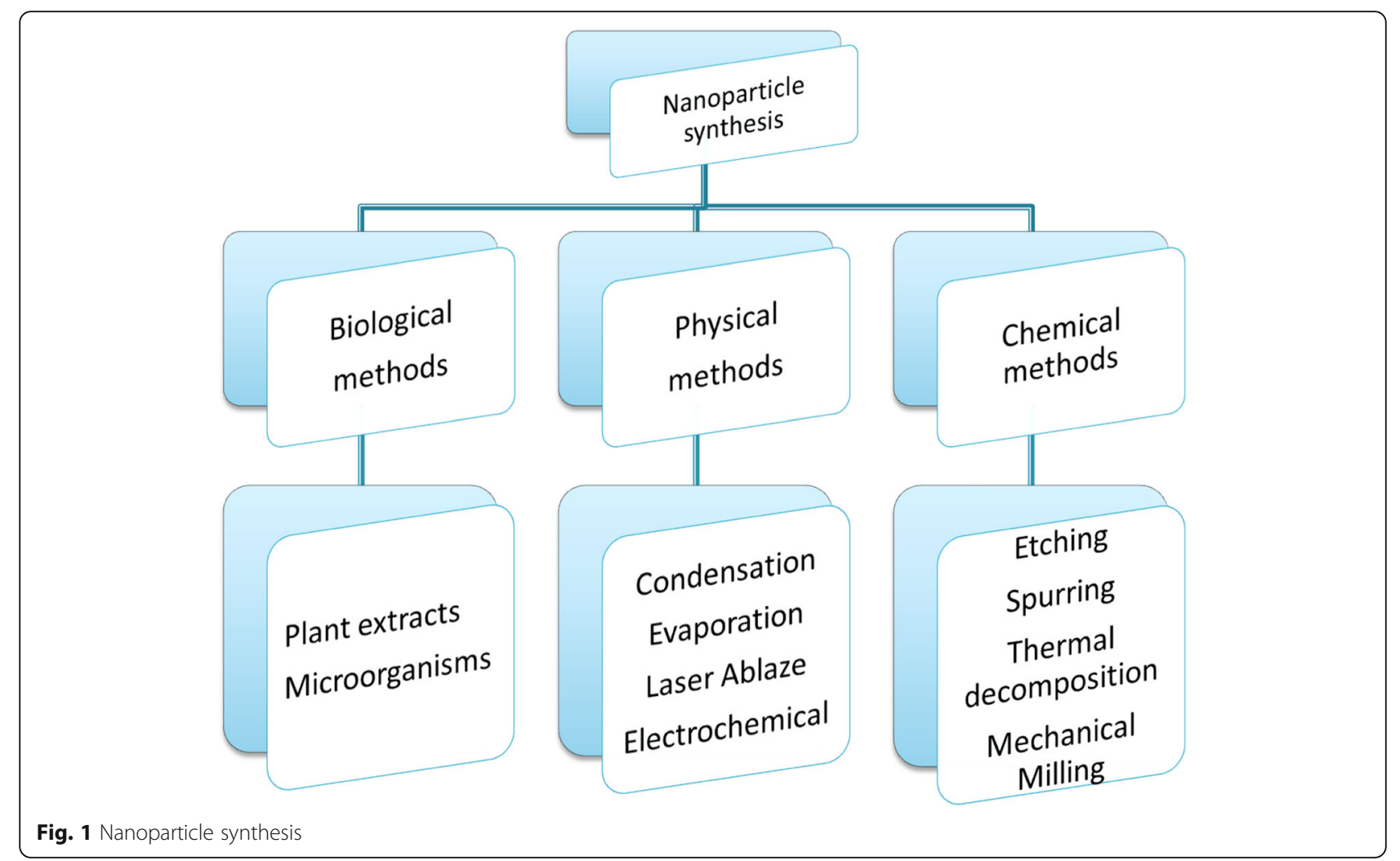

Important dictatorial concerns are to be analyzed for nanomaterials which comprise of a description of the term "nanomaterial," listing processes, precise information necessities for risk-assessment, management and terms to boost the clearness, and recording of the marketable usages, as cataloging or informing to a record for goods containing [114-116]. The general characteristics of nanoparticles and their effects are summed up in Table 6.

\subsection{Nanomaterial toxicity}

The environment and an individual get the exposure to nanoparticles either during natural processes [28, 129] or during their manufacture, distribution, usage, clearance, and waste management. Nanoparticles get released in the environment either accidently or gradually during their synthesis, transport, storage, applications, or disposal methods. In some applications, like nanoremediation, significant amount of nanoparticles are deliberately being introduced to detoxify and transform the environment. The nanoscale dimension of these particles aids their movement in various body parts causing different types of cancers, swelling and damage of organs, protein denaturation and asthmatics attacks, etc. The enhanced surface area and great tendency to bind facilitates the adsorption and transportation of pollutants through long distances over a longer period of time.
There is not much information available about the effects of nanoparticles on the environment. Further research is required to mend the knowledge and information gap about the characteristic behavior of nanoparticles in soil, air, and water and their accumulative properties in food-chains.

Since nanotechnology is still in its nascent stage, there are questions about the effect of industrial and commercial use of nanotechnology on environment and organisms. During their production, nanoparticles might get released in the air, water, or soil in turn affecting the environment and organisms $[130,131]$. The regular assessment of nanoparticles is very much necessary because every application of them creates a new environmental impact. The eco-toxicological effects and the consequences of accumulation of nanoparticles in organisms need more and more research. The alien matters to the human body are normally trapped by the skin and hairs of the organs, while human gastrointestinal tract and the lungs are most susceptible to the infections [132, 133]. Nanoparticles if inhaled by the organism can readily get to the heart, liver, and blood cells through the bloodstream. The tiny dimensions of nanoparticles can facilitate irreparable oxidative strain, denaturation of protein, internal organ injury, agitation of phagocyte functions and asthmatic and cancerous infections, and production of neo-antigens causing organ magnifications and non-functioning. It is being observed that many of 


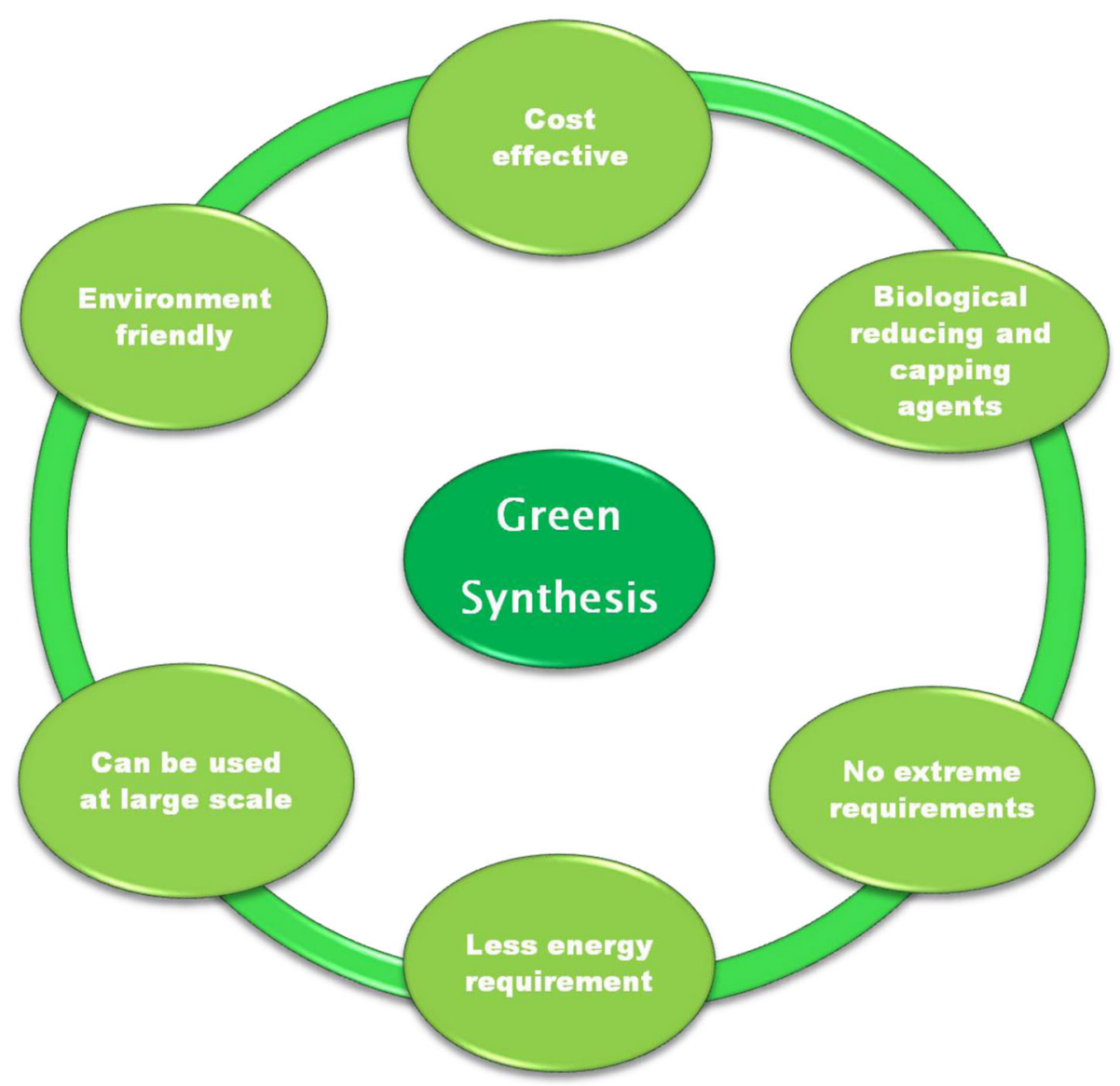

Fig. 2 Green synthesis method

the nanoparticles are non-hazardous, whereas some have the tendency of having positive health effects. As per the data available, the toxicity of nanomaterials is based on a variety of characteristics [134-136].

i. Their dosage and the time of exposure effect ii. The concentration and aggregation property effect

iii. The crystal structure, shape, and size effect

iv. The surface fictionalization and area effect

Various policies in the form of rules, laws, and legislations are being taken into practice by some organizations to reduce or evade the risks linked with

Table 6 General characteristics and risks of nanoparticles

\footnotetext{
1. Nanomaterial properties

2. Aggregation

3. Reactivity

4. Impurity

5. Contaminant dissociation

6. Size

7. Disposal and recycling
}

\section{Risk description}

Aggregation of nanoparticles pose considerable threat as it leads to phase changes, reduced resistance towards corrosion, and increase in the solubility causing the weathering of structures [117, 118].

The spontaneous degradation reactions of nanoparticles may lead to alterations in the functional group-based properties of compounds $[119,120]$.

High reactivity of nanoparticles makes them react with impurities changing their outcomes; therefore, these are encapsulated with non-reactive species [121, 122].

The contaminations in the metal and nonmetal impurities like sulfur, rubidium, and yttrium of nanoparticles are significant risk agents $[123,124]$.

The outstanding size-based properties of nanoparticles are severely affected by their agglomeration nature [125, 126].

The disposal policies of nanomaterials are not well defined, and toxicity-related statistics are not much available for nanomaterials. Therefore, the ambiguity in the effects of nanomaterials has to be resolved to develop significant disposal policies $[127,128]$. 
nanomaterials. However, there are not distinct legal definitions, regulations, and protocols for creation, management, cataloging, testing, and evaluating the effects of nanoparticles on environment. The toxicity listing of nanomaterials is an extremely stipulated study area in current times $[137,138]$. Nanoparticles, if inhaled by the organism can readily get to the heart, liver, and blood cells through the bloodstream. The tiny dimensions of nanoparticles can facilitate irreparable oxidative strain, denaturation of protein, internal organ injury, agitation of phagocyte functions and asthmatic and cancerous infections, and production of neoantigens causing organ magnifications and nonfunctioning. It is being observed that many of the nanoparticles are non-hazardous, whereas some have the tendency of having positive health effect.

\section{Conclusion}

Nanotechnology innovations are still in laboratory stage, generally incoherent from the public and areas where these are ultimately being practiced. Consequently, the people interact with technological advances merely as customers, for their commercialization, and when there is a conflict with the social values, the technology faces resistance. For the broad acceptance of nanotechnology, it is very much necessary to have a balance between the production, marketing, usage, risk assessment, and management of nanoparticles. Without proper regulations and legislations, the usages of nanotechnology may lead to serious grievances causing irreparable damage to the environment and mankind. More and more research and progressive work is still needed to find new cost-effective green synthesis routes, legislation bound usages, and risks and hazard assessment and their solutions. Imparting these points will result into the successful nanoinventions.

\section{Acknowledgements \\ I would like to show gratitude to the Deputy Registrar and the Dean CL of SRM-IST, NCR Campus, my HOD, and colleagues who provided insights, ex- pertise, and support that greatly assisted the research.}

\section{Authors' contributions}

GP has collected and formatted the article, and PJ did the editing and typing work. All authors have read and approved the manuscript

\section{Funding}

No funding involved

\section{Availability of data and materials \\ Not applicable}

\section{Ethics approval and consent to participate}

Not applicable

\section{Consent for publication}

Not applicable

\section{Competing interests}

No competing interest
Received: 18 January 2020 Accepted: 16 November 2020

Published online: 10 December 2020

\section{References}

1. Uskoković V (2007) Nanotechnologies: what we do not know. Technol Soc 29:43-61

2. Yashveer S, Singh V, Kaswan V, Kaushik A, Tokas J (2014) Green biotechnology, nanotechnology and bio-fortification: perspectives on novel environment-friendly crop improvement strategies. Biotechnol Genet Eng Rev 30:113-126

3. Beumer K (2015) The co-production of nanotechnology and development in India, South Africa, and Kenya. In: Bowman DM, Dijkstra A, Fautz C, Guivant J, Konrad K, van Lente H, Woll S (eds) Practices of innovation and responsibility. Insights from methods, governance and action. IOS Press, Berlin, pp 85-98

4. Erbis S, Ok Z, Isaacs JA, Benneyan JC, Kamarthi S (2016) Review of research trends and methods in nano environmental, health, and safety risk analysis. Risk Analysis 36(8):1644-1665

5. Ali MA, Rehman I, lqbal A, Din S, Rao AQ, Latif A, Samiullah TR, Azam S, Husnain T (2014) Nanotechnology: a new frontier in agriculture. Nanotechnology, a new frontier in Agriculture. Adv Life Sci 1(3):129-138

6. ISO/TS 80004-1:2010 (2010) Nanotechnology - vocabulary - part 1: core terms. International Organization for Standardization, Geneva https://www. iso.org/standard/51240.html

7. Jeevanandam J, Barhoum A, Chan YS, Dufresne A, Danquah MK (2018) Review on nanoparticles and nanostructured materials: history, sources, toxicity and regulations. Beilstein J Nanotechnol 9:1050-1074. https://doi. org/10.3762/bjnano.9.98

8. De Matteis V (2017) Exposure to inorganic nanoparticles: routes of entry, immune response, biodistribution and in vitro/in vivo toxicity evaluation. Toxics 5:29. https://doi.org/10.3390/toxics5040029

9. Fraceto LF, Grillo R, de Medeiros GA, Scognamiglio V, Rea G, Bartolucci C (2016) Nanotechnology in agriculture: which innovation potential does it have? Front Environ Sci 4:20. https://doi.org/10.3389/fenvs.2016.00020

10. Glenn JC, Florescu E (2016) Millennium project team. 2015-16 state of the future. J Socialomics 5:1-6. https://doi.org/10.4172/2167-0358.1000168

11. Ezz El-Din H, Manjaiah DH (2017) Internet of nano things and industrial internet of things. In: Acharjya D, Geetha M (eds) Internet of things: novel advances and envisioned applications. Studies in Big Data. Springer, Cham, pp 109-123. https://doi.org/10.1007/978-3319-53472-5_5

12. Xiao L, Takada H, Maeda K, Haramoto M, Miwa N (2005) Antioxidant effects of water-soluble fullerene derivatives against ultraviolet ray or peroxylipid through their action of scavenging the reactive oxygen species in human skin keratinocytes. Biomed Pharmacother 59:351-358. https://doi.org/10. 1016/j.biopha.2005.02.004

13. Corsi I, Winther-Nielsen M, Sethi R, Punta C, Della Torre C, Libralato G, Lofrano G, Sabatini L, Aiello M, Fiordi L, Cinuzzi F, Caneschi A, Pellegrini D, Buttino I (2018) Ecofriendly nanotechnologies and nanomaterials for environmental applications: key issue and consensus recommendations for sustainable and ecosafe nanoremediation. Ecotoxicology and Environmental Safety 154:237-244 https://doi.org/10.1016/j.ecoenv.2018.02.037

14. Bora T, Dutta J (2014) Applications of nanotechnology in wastewater treatment - a review. J Nanosci Nanotechnol 14:613-626

15. Clayton S, Devine-Wright P, Stern PC, Whitmarsh L, Carrico A, Steg L, Swim J, Bonnes M (2015) Psychological research and global climate change. Nat Climate Chang 5:640-646

16. Coccia M (2015) General sources of general purpose technologies in complex societies: theory of global leadership-driven innovation, warfare and human development. Technol Soc 42:199-226

17. Dasgupta N, Ranjan S, Mundekkad D, Ramalingam C, Shanker R, Kumar A (2015) Nanotechnology in agro-food: from field to plate. Food Res Int 69: 381-400

18. McGuire S (2013) WHO, World Food Programme, and International Fund for Agricultural Development. 2012. The state of food insecurity in the world 2012. Economic growth is necessary but not sufficient to accelerate reduction of hunger and malnutrition. Rome, FAO. Adv Nutr 4:126-127

19. Sharma K, Sharma R, Shit S, Gupta S (2012) Nanotechnological application on diagnosis of a plant disease. International conference on advances in biological and medical sciences, Singapore, pp 149-150 
20. Bertoldo R, Mays C, Poumadère M, Schneider N, Svendsen C (2016) Great deeds or great risks? Scientists' social representations of nanotechnology. J Risk Res 19(6):760-779

21. Wang Y, Li Y, Pennell KD (2008) Influence of electrolyte species and concentration on the aggregation and transport of fullerene nanoparticles in quartz sands. Environ Toxicol Chem 27:1860-1867. https://doi.org/10. 1897/08-039.1

22. Chhipa H (2016) Nanofertilizers and nanopesticides for agriculture. Environ Chem Lett 15:15-22. https://doi.org/10.1007/s10311-016-0600-4

23. Abbas SS, Haneef M, Lohani M, Tabassum H, Khan AF (2016) Nanomaterials used as a plants growth enhancer: an update. Int J Pharm Sci Rev Res 5:17-23

24. Baker S, Volovab T, Prudnikovac SV, Satishd S, Prasad NMN (2017) Nanoagroparticles emerging trends and future prospect in modern agriculture system. Environ Toxicol Pharmacol 53:10-17. https://doi.org/10. 1016/j.etap.2017.04.012

25. Rienzie R, Ramanayaka S, Adassooriya NM (2019) Nanotechnology applications for the removal of environmental contaminants from pharmaceuticals and personal care products. In: Pharmaceuticals and personal care products: waste management and treatment technology, pp 279-296. https://doi.org/10.1016/B978-0-12-816189-0.00012-3

26. De Volder MFL, Tawfick SH, Baughman RH, Hart AJ (2013) Carbon nanotubes: present and future commercial applications. Science 1(339):535539. https://doi.org/10.1126/science.1222453

27. Pósfai MR, Lia J, Hobbs PV, Buseck PR (2003) Individual aerosol particles from biomass burning in southern Africa: 2, compositions and aging of inorganic particles. J Geophys Res Atmos 108:8483. https://doi.org/10.1029/ 2002JD002291

28. Nanotechnology prohibited from Australian certified organic beauty productss (2012). http://www.fatcow.com.au/c/biological-farmers-ofaustralia-bfa/nanote chnology-prohibited-from-australian-certified-organicbeauty-productsn914841

29. Pandey $G$ (2018) Challenges and future prospects of agri-nanotechnology for sustainable agriculture in India. Environ Technol Innov 11:299-307

30. Nanomaterials (2012). https://echa.europa.eu/regulations/nanomaterials

31. Chen H, Yada R (2011) Nanotechnologies in agriculture: new tools for sustainable development. Trends Food Sci Technol 22:585-594

32. Rai PK, Kumar V, Lee SS, Raza N, Kim K-H, Ok YS, Tsang DCW (2018) Nanoparticle-plant interaction: implications in energy, environment, and agriculture. Environment International. 119:1-19. https://doi.org/10.1016/j. envint.2018.06.012

33. Yan L, George C, Xiuli Y, Huining D (2019) Preparation of layer-by-layer nanofiltration membranes by dynamic deposition and crosslinking. Membranes 9:20. https://doi.org/10.3390/membranes9020020

34. Pandey G (2019) Biomass based bio-electro fuel cells based on carbon electrodes: an alternative source of renewable energy. SN Applied Sciences 1:408 https://doi.org/10.1007/s42452-019-0409-4

35. de Oliveira JL, Campos EV, Bakshi M, Abhilash PC, Fraceto LF (2014) Application of nanotechnology for the encapsulation of botanical insecticides for sustainable agriculture: prospects and promises. Biotechnol Adv 32:1550-1561

36. Quist-Jensen CA, Macedonio F, Drioli E (2015) Membrane technology for water production in agriculture: desalination and wastewater reuse. Desalination. 364:17-32 https://doi.org/10.1016/j.desal.2015.03.001

37. Cox A, Venkatachalam P, Sahi S, Sharma N (2017) Reprint of: silver and titanium dioxide nanoparticle toxicity in plants: a review of current research. Plant Physiol Biochem 110:33-49. https://doi.org/10.1016/j.plaphy.2016.08.007

38. Kumar S, Nehra M, Dilbaghi N, Marrazza G, Hassan AA, Kim KI-H (2019) Nano-based smart pesticide formulations: emerging opportunities for agriculture. J Control Release 294:131-153 https://doi.org/10.1016/j.jconrel. 2018.12.012

39. Liu C, Gallagher JJ, Sakimoto KK, Nichols EM, Chang CJ, Chang MCY, Yang P (2015) Nanowire-bacteria hybrids for unassisted solar carbon dioxide fixation to value-added chemicals. Nano Lett 15:3634-3639

40. Valentini F, Carbone M, Palleschi G (2013) Carbon nanostructured materials for applications in nano-medicine, cultural heritage, and electrochemical biosensors. Anal Bioanal Chem 405:451-465

41. Bakhtiari M, Moaveni P, Sani B (2015) The effect of iron nanoparticles spraying time and concentration on wheat. Biol Forum Int J 7:679-683

42. Aklakur M, Rather MA, Kumar N (2016) Nano delivery: an emerging avenue for nutraceuticals and drug delivery. Crit Rev Food Sci Nutr 56(14):23522361. https://doi.org/10.1080/10408398.2013.839543
43. Dayarathne HNP, Jeong S, Jang A (2019) Chemical-free scale inhibition method for seawater reverse osmosis membrane process: air micro-nano bubbles. Desalination 461(1):1-9

44. Maynard, A., 2013. Inventory finds increase in consumer products containing nanoscale materials., http://www.nanotechproject.org/news/ archive/9242/

45. Nanomaterial fact sheet. Oakland, CA, U.S.A. (2015). https://archive.asyousow org/wp-content/uploads/2015/03/nanomaterials-in-food-and-foodpackaging-fact-sheet.pdf.

46. Patra JK, Baek K-H (2017) Antibacterial activity and synergistic antibacterial potential of biosynthesized silver nanoparticles against food borne pathogenic bacteria along with its anticandidal and antioxidant effects. Front Microbiol 8:167. https://doi.org/10.3389/fmicb.2017.00167

47. Amin M (2018) Nanofiltration systems and applications in wastewater treatment: review article. Ain Shams Eng J 9. https://doi.org/10.1016/j.asej. 2018.08.001

48. Wang $L$, Hu C, Shao $L$ (2017) The antimicrobial activity of nanoparticles: present situation and prospects for the future. Int J Nanomed 12:1227-1249. https://doi.org/10.2147/IJN.S121956

49. Roseboro K (2011) FDA ignored own scientists' warnings about GM foods, The Organic \& Non-GMO Report

50. Lam SJ, Wong EHH, Boyer C, Qiao GG (2018) Antimicrobial polymeric nanoparticles. Prog Polymer Sci 76:40-64

51. Besley JC, Kramer VL, Priest SH (2008) Expert opinion on nanotechnology: risks, benefits, and regulation. J Nanoparticle Res 10(4):549-558

52. Schummer J (2007) The impact of nanotechnologies on developing countries. In: Allhoff F, Lin P, Moor J, Weckert J (eds) Nanoethics: the ethical and social implications of nanotechnology. Wiley, Hoboken, pp 291-307

53. Steger R, Sung Hoon K, Kazerooni H (2006) Control scheme and networked control architecture for the Berkeley lower extremity exoskeleton (BLEEX). In: Robotics and automation, 2006. ICRA 2006. Proceedings 2006 IEEE international conference on, pp 3469-3476

54. Kookana RS, Boxall AB, Reeve PT, Ashauer R, Beulke S, Chaudhry Q, Cornelis G, Fernandes TF, Gan J, Kah M, Lynch I, Ranville J, Sinclair C, Spurgeon D, Tiede K, Van den Brink PJ (2014) Nanopesticides: guiding principles for regulatory evaluation of environmental risks. J Agric Food Chem 62:4227-4240

55. Nasrollahzadeh M, Sajadi SM, Sajjadi M, Issaabadi Z (2019) Applications of nanotechnology in daily life. Interface Sci Technol 28:113-143

56. Scarano G, Morelli E (2003) Properties of phytochelatin-coated CdS nanocrystallites formed in a marine phytoplanktonic alga (Phaeodactylum tricornutum, Bohlin) in response to Cd. Plant Sci 165:803-810. https://doi. org/10.1016/S0168-9452(03)00274-7

57. Wang P, Zhao F-J, Kopittke PM (2019) Engineering crops without genome integration using nanotechnology. Trends Plant Sci 24(7):574-577 https://doi.org/10.1016/j.tplants.2019.05.004

58. Sadat-Shojai M, Atai M, Nodehi A, Khanlar LN (2010) Hydroxyapatite nanorods as novel fillers for improving the properties of dental adhesives: synthesis and application. Dent Mater 26:471-482. https://doi.org/10.1016/j. dental.2010.01.005

59. Weir A, Westerhoff P, Fabricius L, Hristovski K, Von Goetz N (2012) Titanium dioxide nanoparticles in food and personal care products Environ. Sci Technol 46:2242-2250. https://doi.org/10.1021/es204168d

60. Donaldson K, Stone V, Tran CL, Kreyling W, Borm PJA (2004) A new frontier in particle toxicology relevant to both the workplace and general environment and to consumer safety. Occup Environ Med. 61:727-728. https://doi.org/10.1136/oem.2004.013243

61. Cao, G., 2011. Nanostructures and nanomaterials, synthesis, properties and applications, World Scientific: https://doi.org/10.1142/7885

62. Zhu CL, Zeng XC, Wang EG, Meng S (2013) Quantized water transport: ideal desalination through graphyne-4 membrane. Sci Rep 3:3163

63. Lovric J, Cho SJ, Winnik FM, Maysinger D (2005) Unmodified cadmium telluride quantum dots induce reactive oxygen species formation leading to multiple organelle damage and cell death. Chem Biol 12:1227-1234

64. Dahabieh MS, Bröring S, Maine E (2018) Overcoming barriers to innovation in food and agricultural biotechnology. Trends Food Sci Technol 79:204213 https://doi.org/10.1016/j.tifs.2018.07.004

65. Goswami A, Roy I, Sengupta S, Debnath N (2010) Novel applications of solid and liquid formulations of nanoparticles against insect pests and pathogens. Thin Solid Films 519:1252-1257 https://doi.org/10.1016/j.tsf.2010. 08.079 
66. Vandergheynst JS, Scher H, Hong-Yun G (2006) Design of formulations for improved biological control agent viability and sequestration during storage. Ind Biotechnol 2:213-219

67. Oh D-Y, Noguchi T, Kitagaki R, Park W-J (2014) $\mathrm{CO}_{2}$ emission reduction by reuse of building material waste in the Japanese cement industry Renewable Sustainable Energy Rev 38:796-810

68. Allen MJ, Tung VC, Kaner RB (2009) Honeycomb carbon: a review of graphene. Chem Rev 110(1):132-145

69. Gojny F, Wichmann M, Köpke U, Fiedler B, Schulte K (2004) Carbon nanotubereinforced epoxy-composites: enhanced stiffness and fracture toughness at low nanotube content. Composites Sci Technol 64(15):2363-2371

70. Restuccia L, Ferro GA (2016) Promising low cost carbon-based materials to improve strength and toughness in cement composites. Constr Build Mater 126:1034-1043

71. Nakano T, Suda T, Okaie Y, Moore MJ, Vasilakos AV (2014) Molecular communication among biological nanomachines: a layered architecture and research issues. IEEE Trans Nanobiosci 13(3):169-197

72. Kuscu M, Akan OB (2016) The internet of molecular things based on fret. IEEE Internet Things J 3(1):4-17

73. Stelzner M, Dressler F, Fischer S (2016) Function centric networking: an approach for addressing in in-body nano networks. In: Proceedings of the 3rd ACM International Conference on Nanoscale Computing and Communication, ACM, p 38

74. Systems C (2017) Demystifying SDN for the Network Engineer, Cisco, CA, USA, white paper Edition

75. Mohanpuria P, Rana NK, Yadav SK (2008) Biosynthesis of nanoparticles: technological concepts and future applications. J Nanopart Res 10:507-517. https://doi.org/10.1007/s11051-007-9275-x

76. Fireman EM, Lerman Y, Ganor E, Greif J, Fireman-Shoresh S, Lioy PJ, Banauch Gl, Weiden M, Kelly KJ, Prezant DJ (2004) Induced sputum assessment in New York City firefighters exposed to World Trade Center dust. Environ Health Perspect 112:1564-1569. https://doi.org/10.1289/ehp.7233

77. Godtfredsen NS, Osler M, Vestbo J, Andersen I, Prescott E (2003) Smoking reduction, smoking cessation, and incidence of fatal and non-fatal myocardia infarction in Denmark 1976-1998: a pooled cohort study. J Epidemiol Community Health 57:412-416. https://doi.org/10.1136/jech.57.6.412

78. Stefani $D$, Wardman $D$, Lambert $T$ (2005) The implosion of the Calgary General Hospital: ambient air quality issues. J Air Waste Manage Assoc 55: 52-59. https://doi.org/10.1080/10473289.2005.10464605

79. Riediker M, Devlin RB, Griggs TR, Herbst MC, Bromberg PA, Williams RW, Cascio WE (2004) Cardiovascular effects in patrol officers are associated with fine particulate matter from brake wear and engine emissions. Part Fibre Toxicol 4:1, No. 2. https://doi.org/10.1186/1743-8977-1-2

80. Bigert C, Gustavsson P, Hallqvist J, Hogstedt C, Lewné M, Plato N, Reuterwall C, Schéele P (2003) Myocardial infarction among professional drivers. Epidemiology 14:333-339. https://doi.org/10.1097/01.EDE.0000057141.91012.80

81. Rogers F, Arnott P, Zielinska B, Sagebiel J, Kelly KE, Wagner D, Lighty JS, Sarofim AF (2005) Real-time measurements of jet aircraft engine exhaust. J Air Waste Manage Assoc 55:583-593. https://doi.org/10.1080/10473289.2005. 10464651

82. Gour, A., Jain N.K., 2019. Advances in green synthesis of nanoparticles, Artif Cells Nanomed Biotechnol. 47, 844-851, DOl; https://doi.org/10.1080/ 21691401.2019.1577878

83. Kouhkan M, Ahangar P, Babaganjeh LA, Allahyari-Devin M (2019) Biosynthesis of copper oxide nanoparticles using Lactobacillus casei subsp. casei and its anticancer and antibacterial activities. Curr Nanosci. https://doi. org/10.2174/1573413715666190318155801

84. http://www.gaeu.com/item/this-is-nanotechnology-one-of-the-fastestgrowing-markets-in-the-world

85. http://www.nanotechia.org/sectors

86. https://www.ceramicindustry.com/articles/94506-nano-devices-segment-ofglobal-nanotechnology-market-expected-tosee-significant-growth

87. Global nanotechnology market analysis \& trends - industry forecast to 2025 (2016) Accuray Res LLP. https://www.prnewswire.com/news-releases/globalnanotechnology-market-analysis--trends--industry-forecast-to-2025-3003401 82.html

88. Roco MC, Mirkin C, Hersam MC (2011) Nanotechnology research directions for societal needs in 2020. J Nanoparticle Res 13:897-919 www.wtec.org/ NBIC2-Report/

89. Lux Research (2016) In: Kendrick I, Bos A, Chen S (eds) Revenue from nanotechnology (Figure 11), in Nanotechnology Update: U.S. Leads in
Government Spending Amidst Increased Spending Across Asia. Lux Research, Inc. report to NNCO and NSF, New York, p 17

90. Rasheed T, Bilal M, lqbal HMN, Li C (2017) Green biosynthesis of silver nanoparticles using leaves extract of Artemisia vulgaris and their potential biomedical applications. Colloids Surf B Biointerfaces 158:408. https://doi. org/10.1016/j.colsurfb.2017.07.020

91. Skiba M, Vorobyova V (2018) Green synthesis of silver nanoparticles using grape pomace extract prepared by plasma-chemical assisted extraction method. Mol Crystals Liquid Crystals 674:142-151. https://doi.org/10.1080/ 15421406.2019.1578520

92. Hyeon T (2003) Chemical synthesis of magnetic nanoparticles. Chem Commun 8:927-934. https://doi.org/10.1039/b207789b

93. Pirtarighat S, Ghannadnia M, Baghshahi SJ (2019) Green synthesis of silver nanoparticles using the plant extract of Salvia spinosa grown in vitro and their antibacterial activity assessment. Nanostruct Chem 9:1 https://doi.org/ 10.1007/s40097-018-0291-4

94. Husgafvel-Pursiainen K (2004) Mechanistic considerations for air pollution and lung cancer: genotoxicity and molecular biomarker data from experimental and human studies. Mutat Res Rev Mutat Res 567:427-445. https://doi.org/10.1016/j.mrrev.2004.06.004

95. Kouhbanani MAJ, Beheshtkhoo N, Taghizadeh S, Amani AM, Alimardani V (2019) One-step green synthesis and characterization of iron oxide nanoparticles using aqueous leaf extract of Teucrium polium and their catalytic application in dye degradation. Adv Nat Sci Nanosci Nanotechnol 10:015007 https://doi.org/10.1088/2043-6254/aafe74

96. Linak WP, Miller CA, Wendt JOL (2000) Comparison of particle size distributions and elemental partitioning from the combustion of pulverized coal and residual fuel oil. J Air Waste Manage Assoc 50:1532-1544. https:// doi.org/10.1080/10473289.2000.10464171

97. Buseck PR, Adachi K (2008) Nanoparticles in the atmospheree. Elements 4: 389-394. https://doi.org/10.2113/gselements.4.6.389

98. Prabhu NN (2018) Green synthesis of iron oxide nanoparticles (IONPs) and their nanotechnological applications. J Bacteriol Mycol 6(4):260-262 https://doi.org/10.15406/jbmoa.2018.06.00215

99. El-Refai AA, Ghoniem GA, El-Khateeb AY, Hassaan MM (2018) Eco-friendly synthesis of metal nanoparticles using ginger and garlic extracts as biocompatible novel antioxidant and antimicrobial agents. J Nanostruct Chem 8:71-81. https://doi.org/10.1007/s40097-018-0255-8

100. Krumov N, Perner-Nochta I, Oder S, Gotcheva V, Angelov A, Posten C (2009) Production of inorganic nanoparticles by microorganisms. Chem Eng Technol 32:1026-1035. https://doi.org/10.1002/ceat.200900046

101. Soil Association bans nanomaterials from organic products. The Guardian: London, United Kingdom, 2008. https://www.theguardian.com/ environment/2008/jan/15/organics.nanotechnology

102. Senjen R (2012) Nanotechnology and patents - how can potential risks be assessed? Recent Pat Food Nutr Agric 4:245-249

103. Mabe FN, Talabi K, Danso-Abbeam G (2017) Awareness of health implications of agrochemical use: effects on maize production in EjuraSekyedumase municipality, Ghana. Adv Agric 11 Article ID 7960964. https://doi.org/10.1155/2017/7960964

104. Choi J-Y, Ramachandran G, Kandlikar M (2009) The impact of toxicity testing costs on nanomaterial regulation. Environ Sci Technol 43(9):3030-3034

105. Amenta V, Aschberger $\mathrm{K}$, Arena M, Bouwmeester $\mathrm{H}$, Moniz FB, Brandhoff $\mathrm{P}$, Gottardo S, Marvin HJP, Mech A, Pesudo LQ, Rauscher H, Schoonjans R, Vettori MV, Weigel S, Peters RJ (2015) Regulatory aspects of nanotechnology in the agri/feed/food sector in EU and non-EU countries. Regul Toxicol Pharmacol 73(1):463-476 https://doi.org/10.1016/j.yrtph.2015.06.016

106. Dhawan A, Shanker R, Das M, Gupta KC (2011) Guidance for safe handling of nanomaterials. J Biomed Nanotechnol 7(1):218-224

107. Hristozov DR, Gottardo S, Critto A (2012) Risk assessment of engineered nanomaterials: a review of available data and approaches from a regulatory perspective. Nanotoxicology 6(8):880-898

108. OECD (Organisation for Economic Co-operation and Development) (2011) Nanosafety at the OECD: the first five years 2006-2010. OECD, Paris

109. Wright IA, Tarawali S, Blummel M, Gerard B, Teufel N, Herrero M (2012) Integrating crops and livestock in subtropical agricultural systems. J Sci Food Agric 92:1010-1015

110. Wu SH, Ho CT, Nah SL, Chau CF (2014) Global hunger: a challenge to agricultural, food, and nutritional sciences. Crit Rev Food Sci Nutr 54:151-162

111. Pandey G (2018) Nanotechnology for achieving green-economy through sustainable energy. Rasayan J Chem 11(3):942-950 
112. Coles D, Frewer $L$ (2013) Nanotechnology applied to European food production - a review of ethical and regulatory issues. Trends Food Sci Technol 34(1):32-43 https://doi.org/10.1016/j.tifs.2013.08.006

113. Pandey G (2018) Prospects of nanobioremediation in environmental cleanup. Orient J Chem 34(6) https://doi.org/10.13005/ojc/340622

114. Steinhäuser KG, Sayre PG (2017) Reliability of methods and data for regulatory assessment of nanomaterial risks. Nanolmpact 7:66-74 https://doi.org/10.1016/j.impact.2017.06.001

115. Seyedi N, Saidi K, Sheibani H (2018) Green synthesis of Pd nanoparticles supported on magnetic graphene oxide by Origanum vulgare leaf plant extract: catalytic activity in the reduction of organic dyes and SuzukiMiyaura cross-coupling reaction. Catalysis Lett 148:277-288

116. Kanchi S, Kumar GK, Lo A-Y, Tseng CM, Chen SK, Lin CY, Chin TS (2018) Exploitation of de-oiled Jatropha waste for gold nanoparticles synthesis: a green approach. Arab J Chem. 11:247 https://doi.org/10.1016/j.arabjc.2014. 08.006

117. Kennedy AJ, Hull MS, Steevens JA, Dontsova KM, Chappell MA, Gunter JC, Weiss CA (2008) Factors influencing the partitioning and toxicity of nanotubes in the aquatic environment. Environ Toxicol Chem 27:19321941. https://doi.org/10.1897/07-624.1 J. C., Weiss, C. A., Jr.

118. Sayre PG, Steinhäuser KG, Teunenbroe T-v (2017) Methods and data for regulatory risk assessment of nanomaterials: questions for an expert consultation. Nanolmpact 8:20-27 https://doi.org/10.1016/j.impact.2017.07.001

119. Tervonen T, Linkov I, Figueira JR, Steevens J, Chappell M, Merad M (2009) Risk-based classification system of nanomaterials. J Nanopart Res 11:757766. https://doi.org/10.1007/s11051-008-9546-1

120. Radad K, Al-Shraim M, Moldzio R, Rausch W-D (2012) Recent advances in benefits and hazards of engineered nanoparticles. Environ Toxicol Pharmacol 34(3):661-672 https://doi.org/10.1016/j.etap.2012.07.011

121. Rushton $L$ (2004) Health impact of environmental tobacco smoke in the home. Rev Environ Health 19:291-309

122. Justo-Hanani R, Dayan T (2015) European risk governance of nanotechnology: explaining the emerging regulatory policy. Res Policy 44(8):1527-1536 https://doi.org/10.1016/j.respol.2015.05.001

123. Johnson VR (2016) Nanotechnology, environmental risks, and regulatory options. Penn St L Rev 121:471-503

124. Di Sia P (2017) Nanotechnology among innovation, health and risks. Proc Soc Behav Sci. 237:1076-1080 https://doi.org/10.1016/j.sbspro.2017.02.158

125. Thomas T, Thomas K, Sadrieh N, Savage N, Adair P, Bronaugh R (2006) Research strategies for safety evaluation of nanomaterials, part VII: evaluating consumer exposure to nanoscale materials. Toxicol Sci 91:14-19. https://doi.org/10.1093/toxsci/kfj129

126. He X, Deng H, Hwang H-m (2019) The current application of nanotechnology in food and agriculture. J Food Drug Anal. 27(1):1-21 https://doi.org/10.1016/j.jfda.2018.12.002

127. Principles for the oversight of nanotechnologies and nanomaterials (2007) http://www.icta.org/files/2012/04/080112_ICTA_rev1.pdf.

128. Morales-Díaz AB, Ortega-Ortíz H, Juárez-Maldonado A, Cadenas-Pliego G, GonzálezMorales S, Adalberto B-MA (2017) Application of nanoelements in plant nutrition and its impact in ecosystems. Adv Nat Sci Nanosci Nanotechnol 8:1-13. https://doi.org/10.1088/2043-6254/8/1/013001

129. Mufamadi MS, Sekhejane PR (2017) Nanomaterial-based biosensors in agriculture application and accessibility in rural smallholding farms: food security. In: Prasad R, Kumar M, Kumar V (eds) Nanotechnology. Springer, Singapore, pp 263-278. https://doi.org/10.1007/978-981-10-4573-8_12

130. Monteiro-Riviere NA, Wiench K, Landsiedel R, Schulte S, Inman AO, Riviere JE (2011) Safety evaluation of sunscreen formulations containing titanium dioxide and zinc oxide nanoparticles in UVB sunburned skin: an in vitro and in vivo study. Toxicol Sci 123:264-280. https://doi.org/10.1093/toxsci/kfr148

131. Yang Y, Qin Z, Zeng W, Yang T, Cao Y, Me C, Kuang Y (2017) Toxicity assessment of nanoparticles in various systems and organs. Nanotechnol Rev 6(3):279-228

132. Marchant GE, Sylvester DJ, Abbott KW, Danforth TL (2009) International harmonization of regulation of nanomedicine. Stud Ethics Law Technol 3:1-14

133. Ajazzuddin M, Jeswani G, Kumar Jha A (2015) Nanocosmetics: past, present and future trends. Recent Pat Nanomed. 5:3-11. https://doi.org/10.2174/ 1877912305666150417232826

134. Ferro G, Tulliani J, Lopez A, Jagdale P (2015) New cementitious composite building material with enhanced toughness. Theor Appl Fracture Mech 76: $67-74$
135. Hosea M, Greene B, Mcpherson R, Henzl M, Alexander MD, Darnall DW (1986) Accumulation of elemental gold on the alga Chlorella vulgaris. Inorg Chim Acta 123:161-165. https://doi.org/10.1016/S0020-1693(00)86339-2

136. D'Silva J, van Calster G (2009) Taking temperature - a review of European Union regulation in nanomedicine. Eur J Health Law 16:249-269. https://doi.org/10.1163/157180909X453071

137. Sastry M, Ahmad A, Khan Ml, Kumar R (2003) Biosynthesis of metal nanoparticles using fungi and actinomycete. Curr Sci. 85:162-170

138. Mukherjee P, Senapati S, Mandal D, Ahmad A, Khan Ml, Kumar R, Sastry M (2002) Extracellular synthesis of gold nanoparticles by the fungus Fusarium oxysporum. Chem Bio Chem 3:461-463. https://doi.org/10.1002/14397633(20020503)3:5<461::AID-CBIC461>3.0.CO,2X

\section{Publisher's Note}

Springer Nature remains neutral with regard to jurisdictional claims in published maps and institutional affiliations.

\section{Submit your manuscript to a SpringerOpen ${ }^{\circ}$ journal and benefit from:}

- Convenient online submission

- Rigorous peer review

- Open access: articles freely available online

High visibility within the field

- Retaining the copyright to your article

Submit your next manuscript at $\boldsymbol{\nabla}$ springeropen.com 